\title{
Critical limits of Mehlich 3 extractable phosphorous, potassium, sulfur, boron and zinc in soils for nutrition of rice (Oryza sativa L.)
}

\author{
Anindita Seth ${ }^{1}$, Dibyendu Sarkar ${ }^{2}$, Reginald Ebhin Masto $^{3}$, Kaushik Batabyal ${ }^{2}$, Susmit $^{2}$ \\ $\mathrm{Saha}^{2}$, Sidhu Murmu ${ }^{2}$, Ruma Das ${ }^{4}$, Dhaneshwar Padhan ${ }^{2}$, Biswapati Mandal ${ }^{2}$
}

${ }^{1}$ Department of Soil and Water Sciences, The Robert H. Smith Faculty of Agriculture, Food and Environment, The Hebrew University of Jerusalem, Rehovot-760 100, Israel. ${ }^{2}$ Department of Agricultural Chemistry and Soil Science, Bidhan Chandra Krishi Viswavidyalaya, West Bengal-741 252, India. ${ }^{3}$ Environmental Management Division, Central Institute of Mining and Fuel Research, FRI, Dhanbad-828 108, India. ${ }^{4}$ Division of Soil Science and Agricultural Chemistry, ICAR-Indian Agricultural Research Institute (IARI), Pusa Campus, New Delhi 110 012, India. *Corresponding author: anindita.asg@gmail.com

\begin{abstract}
We evaluated the critical limits of P, K, S, B and $\mathrm{Zn}$ in Inceptisols and Alfisols for nutrition of rice (Oryza sativa L.) using Mehlich 3 as an extractant. Three levels, each of $\mathrm{P}\left(0,14\right.$ and $23 \mathrm{mg} \mathrm{kg}^{-1}$ soil), $\mathrm{K}\left(0,23\right.$ and $36 \mathrm{mg} \mathrm{kg}^{-1}$ soil), $\mathrm{S}\left(0,4.5\right.$ and $9.0 \mathrm{mg} \mathrm{kg}^{-1}$ soil), B (0, 0.5 and $1.0 \mathrm{mg} \mathrm{kg}^{-1}$ soil) and $\mathrm{Zn}\left(0,2.3\right.$ and $4.5 \mathrm{mg} \mathrm{kg}^{-1}$ soil) were applied separately to 20 Alfisols and Inceptisols each for growing rice in greenhouse. Biomass yield, concentration and uptake of those nutrients by rice were significantly influenced $(\mathrm{P} \leq 0.01)$ by the soil and rate of each of the nutrients (P, K, S, B and Zn), but not by their interactions in both the soil orders. The amount of these five nutrients as extracted from soils by Mehlich 3, alike conventional extractants, showed significant positive correlations $(\mathrm{P} \leq 0.01)$ with biomass yield, nutrients concentration and their uptake by rice plant, which indicated suitability of Mehlich 3 in predicting plant available nutrients in soil. The critical levels of Mehlich 3 extractable $\mathrm{P}, \mathrm{K}, \mathrm{S}, \mathrm{B}$ and $\mathrm{Zn}$ for rice in Inceptisols were 14.7, 51.2, 22.9, 0.65 and $1.27 \mathrm{mg} \mathrm{kg}^{-1}$; while in Alfisols those values were $8.2,117.3,21.9,0.40$ and $2.15 \mathrm{mg} \mathrm{kg}^{-1}$, respectively.
\end{abstract}

Keywords: Mehlich 3, suitability, Inceptisols, Alfisols, critical limit, rice. 


\section{Introduction}

Rice (Oryza sativa L.) is the primary staple food for about three billion people in Asia and Africa. It provides $21 \%$ of dietary energy and $15 \%$ of protein requirements to the global population (Gnanamanickam, 2009). Under intensive farming situations, the crop is raised with inadequate supply of nutrients causing deterioration in soil fertility and emergence of multi-nutrient deficiencies in many places (Ladha et al., 2003). Rice is the major crop in the fine-textured alluvial Inceptisols and moderately weathered acidic Alfisols of West Bengal, India. Alternate aerobicanaerobic environment under continuous rice-based cropping systems in these soils caused a decrease in $\mathrm{P}$ availability (Bhattacharyya et al., 2015). Low K fertilization and poor native K supply capacity of Alfisols caused hidden hunger and deficiency of the element. Sulfur deficiency is also common in track of eastern Indo-Gangetic alluvial plains of India, where intensive cropping of oilseeds and pulses is followed with rice (Khurana et al., 2008). Widespread deficiency of $\mathrm{B}$ is also reported from Alfisols (Sarkar et al., 2008) like that of $\mathrm{Zn}$ in Inceptisols (Mandal and Mandal, 1986). Because of these, rice growing Inceptisols and Alfisols in India show deficiency of essential nutrients including micronutrients.

Conventional methods for assessing plant available $\mathrm{P}$ content in soils involve Bray and Kurtz, 1945) and Olsen et al., 1954) for soils having $\mathrm{pH}<6.0$ and $>6.0$, respectively. Ammonium acetate $\left(\mathrm{NH}_{4} \mathrm{OAc}\right)(1.0 \mathrm{M}$ $\mathrm{NH}_{4} \mathrm{OAc}$ at $\mathrm{pH} 7.0$; Hanway and Heidel, 1952), calcium chloride (0.15\% $\mathrm{CaCl}_{2}$; Chesnin and Yien, 1950), diethylenetriaminepentaacetic acid (DTPA) (0.005 $\mathrm{M} \mathrm{DTPA}+0.01 \mathrm{M} \mathrm{CaCl}_{2}+0.1 \mathrm{M}$ triethanolamine, $\mathrm{pH}$ 7.3; Lindsay and Norvell, 1978) and hot- $\mathrm{CaCl}_{2}$ (0.02 $\mathrm{M}$ hot- $\mathrm{CaCl}_{2}$; Parker and Gardner, 1981) are the most commonly used extractants for assessing $\mathrm{K}, \mathrm{S}, \mathrm{Zn}$ and $\mathrm{B}$ availability in soils, respectively. Mehlich $3\left[0.2 \mathrm{M} \mathrm{CH}_{3} \mathrm{COOH}+0.25 \mathrm{M} \mathrm{NH}_{4} \mathrm{NO}_{3}+\right.$ $0.015 \mathrm{M} \mathrm{NH}_{4} \mathrm{~F}+0.013 \mathrm{M} \mathrm{HNO}_{3}+0.001 \mathrm{M}$ ethylene diamine tetraacetic acid (EDTA), $\mathrm{pH}$ 2.5; Mehlich, 1984] method is now used for simultaneous determination of macronutrients and micronutrients. Wendt (1995) found that that Mehlich 3 offered comparable predictions of soil fertility, like other standard soil extractants, for a range of macronutrients and micronutrients. Again, use of a multi-nutrient extractant like Mehlich 3 is advantageous for routine laboratory analysis of available plant nutrients, because it offers the assessment of nutrient status in soil in cost effective and time saving manner by means of simultaneous extraction of a large number of essential nutrients in a single step (Seth et al., 2017; Pradhan et al., 2015).

Determination of critical concentration of essential plant nutrients is useful for an early diagnosis of their deficiency in soils for undertaking corrective measures before growing of crops. Such critical limits of P, K, S, Zn and B in soils for deficiency of various crops were reported by different researchers around the globe (Kumari et al., 2018; Zbiral, 2016; Slaton et al., 2005; Sarkar et al., 2008; Bado et al., 2007; Cox and Barne, 2002).. But these values vary with soil, crop and extractant used. Information regarding suitability of multi-nutrient extractants for assessing availability of $\mathrm{P}, \mathrm{K}, \mathrm{S}, \mathrm{Zn}$ and $\mathrm{B}$ to rice in Inceptisols and Alfisols of India and their critical values is scarce. Keeping the above in view, we evaluated Mehlich 3 method of extraction for assessing availability of these nutrients in Inceptisols and Alfisols for nutrition of rice. 


\section{Materials and Methods}

\subsection{Soil sampling}

Forty surface $(0-0.2 \mathrm{~m})$ soil samples, varying widely in their physicochemical properties, were collected from typical rice growing areas (20 each from Inceptisols and Alfisols) of West Bengal, India. Details of location and classification of the soils were given in our earlier publication (Seth et al., 2017). A portion of the soils was air dried under shade, ground, passed through $2.0 \mathrm{~mm}$ nylon sieve and stored for chemical analysis and the remaining part was used for the pot experiment.

\subsection{Analysis of soil}

The soil samples were analysed for $\mathrm{pH}$ (1:2.5 soil: water), cation exchange capacity (CEC; Sparks et al., 1996), oxidisable organic C (Walkley and Black, 1934) and clay content (International pipette method; Green, 1981). Available P, K, S, Zn and B content in the soils was extracted by Mehlich 3 (Mehlich, 1984) and conventional extractants for respective element. The conventional methods used for estimation of available P were Bray extraction (Bray and Kurtz, 1945) and Olsen extraction (Olsen et al., 1954) for soils having $\mathrm{pH}<6.0$ and $>6.0$, respectively; whereas, available $\mathrm{K}, \mathrm{S}, \mathrm{Zn}$ and $\mathrm{B}$ were extracted using $\mathrm{NH}_{4} \mathrm{OAc}$ (Hanway and Heidel, 1952), $\mathrm{CaCl}_{2}$ (Chesnin and Yien, 1950), DTPA (Lindsay and Norvell, 1978) and hot- $\mathrm{CaCl}_{2}$ (Parker and Gardner, 1981) methods, respectively. For extraction of all the five nutrients from soil by Mehlich 3, a measured quantity of soil was shaken for 5 minutes with soil:extractant ratio $1: 10(\mathrm{w} / \mathrm{v})$ at $27^{\circ} \mathrm{C}$ in polypropylene tubes, then centrifuged at $1200 \mathrm{rpm}$ and filtered through Whatmann No. 42 filter paper. Nutrient content in the extracts was determined by an inductively coupled plasma-atomic emission spectrophotometer (ICP-AES; model: icap 6000 series, Thermo Fisher Scientific, Germany).

\subsection{Greenhouse experiment}

The pot experiment was conducted under controlled conditions at Directorate of Research (22 $2^{\circ} 58.114^{\prime} \mathrm{N}$ latitude and $88^{\circ} 29.543^{\prime}$ E longitude), Bidhan Chandra Krishi Viswavidyalaya, West Bengal, India. Earthen pots with polythene sheeting were filled up with 5.0 $\mathrm{kg}$ of each of the 40 soils. The soils in the pots were then flooded with deionized water, puddled and planted with two healthy, disease free 21-day-old rice seedlings (cv. IET 4786). After settling, the soil in the pots was treated with recommended dose of $\mathrm{N}$ at the rate of $40 \mathrm{mg} \mathrm{kg}^{-1}$. Nitrogen was applied in three equal splits at basal, 20 and 40 days after planting. Based on soil test values, the soils were treated with three increasing levels of P, K, S, B and Zn separately in 40 soils in 3 replicates for each dose of each nutrient to study the effect of individual nutrient on rice. Full amounts of $\mathrm{P}, \mathrm{K}$ and $\mathrm{S}$ were applied at pre-planting basal while $\mathrm{Zn}$ and $\mathrm{B}$ were added after 3 days when the seedlings were established. The applied doses of $\mathrm{P}$ were $0\left(\mathrm{P}_{0}\right)$, $14\left(\mathrm{P}_{1}\right)$ and $23\left(\mathrm{P}_{2}\right) \mathrm{mg} \mathrm{kg}^{-1}$ of soil, $\mathrm{K}$ were $0\left(\mathrm{~K}_{0}\right), 23$ $\left(\mathrm{K}_{1}\right)$ and $36\left(\mathrm{~K}_{2}\right) \mathrm{mg} \mathrm{kg}^{-1}$ of soil, $\mathrm{S}$ were $0\left(\mathrm{~S}_{0}\right), 4.5$ $\left(\mathrm{S}_{1}\right)$ and $9.0\left(\mathrm{~S}_{2}\right) \mathrm{mg} \mathrm{kg}^{-1}$ of soil, B were $0\left(\mathrm{~B}_{0}\right), 0.5$ $\left(\mathrm{B}_{1}\right)$ and $1.0\left(\mathrm{~B}_{2}\right) \mathrm{mg} \mathrm{kg}^{-1}$ of soil and $\mathrm{Zn}$ were $0\left(\mathrm{Zn}_{0}\right)$, $4.5\left(\mathrm{Zn}_{1}\right)$ and $9.0\left(\mathrm{Zn}_{2}\right) \mathrm{mg} \mathrm{kg}{ }^{-1}$ of soil. Application of the nutrient in question at three levels was associated with application of remaining nutrients at their medium level (i.e., for N, P, K, S, Zn and B at 40, 14, $23,4.5,2.3$ and $0.5 \mathrm{mg} \mathrm{kg}^{-1}$ of soil, respectively). The experiment was conducted in completely randomized block design with three replicates for each treatment using a total $1320[(40 \times 3 \times 3)+4 \times(40 \times 2 \times 3)]$ pots. Reagent grade urea $(46.64 \% \mathrm{~N})$, di-ammonium phosphate $(21.21 \% \mathrm{~N}$ and $23.45 \% \mathrm{P})$, potassium chloride $(52.44 \% \mathrm{~K})$, zinc chloride $(47.97 \% \mathrm{Zn})$ and borax 
$(11.33 \%$ B) were used as the source of nutrients to avoid impurities. Pots were irrigated, as and when required, with deionized water maintaining a height of standing water at $5 \pm 0.5 \mathrm{~cm}$ above the soil surface in the pots throughout the growing period. Plants were allowed to grow in the pots up to 50 days after transplanting and harvested.

\subsection{Plant analysis}

Plant samples (rice shoots) were thoroughly washed with de-ionized water and dried in a hot air oven at $60^{\circ} \mathrm{C}$ to a constant weight. Dry matter yield of the shoots was recorded and thereafter, the shoots were milled $(1.0 \mathrm{~mm})$ with the help of a Wiley stainless steel mechanical grinder and used for analysis. Plant samples thus prepared were digested with di-acid mixture of $\mathrm{HNO}_{3}$ and $\mathrm{HClO}_{4}$ in 9:4 ratio (Tandon, 1995) for determination of $\mathrm{P}, \mathrm{K}, \mathrm{S}$ and $\mathrm{Zn}$ concentration in them. However, for B estimation plant samples were ashed in a muffle furnace at $550{ }^{\circ} \mathrm{C}$ for $1.0 \mathrm{~h}$ and subsequently extracted with $0.36 \mathrm{~N} \mathrm{H}_{2} \mathrm{SO}_{4}$ following the method of Gaines and Mitchell (1979). Concentration of nutrients in the digests was determined by ICP-AES.

\subsection{Determination of critical limit}

The critical limits of Mehlich 3 extractable $\mathrm{P}, \mathrm{K}, \mathrm{S}$, $\mathrm{B}$ and $\mathrm{Zn}$ in the experimental soils of both the orders for nutrition of rice were determined by the statistical method as described by Cate and Nelson (1971) using Bray's percent yield as the dependent variable. The Bray's percent yield (BPY) was calculated by using the formula:

$\frac{\text { Yield without nutrient }}{\text { with optimum level of nutrient }} \times 100$

\subsection{Data analysis}

Pearson bivariate correlation coefficient (r) was computed between the amount of $\mathrm{P}, \mathrm{K}, \mathrm{S}, \mathrm{B}$ and $\mathrm{Zn}$ extracted by Mehlich 3 and soil properties. Such coefficients were also computed between the extractable amounts of P, K, S, B and Zn by Mehlich 3 and those by the conventional extractants. The analysis of variance for the effects of soil, nutrient (P, K, S, B and Zn) dose and soil $\times$ nutrient dose interactions were also studied using dry matter yield, plant nutrient concentration and their uptake by rice as the dependent variables. The suitability of Mehlich 3 for assessing available soil nutrients was adjudged by computing correlation between extractable soil nutrients by Mehlich 3 and Bray's percent yield, nutrients concentration and its uptake by rice. Statistical analyses of the data were done using SPSS 17.0 (SPSS Institute Inc., Chicago, IL, USA).

\section{Results}

\subsection{Soil characteristics}

Soil $\mathrm{pH}$ varied from 4.7 to 7.2 and 4.1 to 6.1 with mean values of 6.2 and 5.1 in Inceptisols and Alfisols, respectively, which indicated that the soils of the former order was acidic to neutral, while of later was acidic in reaction. On an average, clay and organic $\mathrm{C}$ content and CEC were higher in Inceptisols than those in Alfisols (Table 1).

\subsection{Extractable $P, K, S, B$ and $Z n$ from soil}

The amount of $\mathrm{P}$ extracted by Mehlich 3 was lower and higher than that extracted by Bray/Olsen method in Inceptisols and Alfisols, respectively. However, Mehlich 3 always extracted higher amount of K, S, B and Zn in both the soil orders than those extracted by the conventional extractants for each of the element (Table 1). 
Table 1. Some important properties and amount of extractable P, K, S, Zn and B of the experimental soils.

\begin{tabular}{|c|c|c|c|c|c|c|}
\hline \multirow[t]{2}{*}{ Soil properties } & \multicolumn{3}{|c|}{ Inceptisols } & \multicolumn{3}{|c|}{ Alfisols } \\
\hline & $\begin{array}{c}\text { Range } \\
\left(\mathrm{mg} \mathrm{kg}^{-1}\right)\end{array}$ & $\begin{array}{c}\text { Mean } \\
\left(\mathrm{mg} \mathrm{kg}^{-1}\right)\end{array}$ & SD & $\begin{array}{c}\text { Range } \\
\left(\mathrm{mg} \mathrm{kg}^{-1}\right)\end{array}$ & $\begin{array}{c}\text { Mean } \\
\left(\mathrm{mg} \mathrm{kg}^{-1}\right)\end{array}$ & SD \\
\hline $\mathrm{pH}(1: 2.5)$ & $4.7-7.2$ & 6.2 & 0.58 & $4.1-6.1$ & 5.1 & 0.49 \\
\hline Organic $\mathrm{C}\left(\mathrm{g} \mathrm{kg}^{-1}\right)$ & $4.1-15.3$ & 9.2 & 2.85 & $3.5-13.7$ & 8.2 & 1.87 \\
\hline $\mathrm{CEC}\left[\mathrm{cmol}\left(\mathrm{p}^{+}\right) \mathrm{kg}^{-1}\right]$ & $6.0-41.1$ & 19.9 & 4.34 & $5.0-24.1$ & 9.1 & 3.37 \\
\hline Clay $\left(\mathrm{g} \mathrm{kg}^{-1}\right)$ & $115-755$ & 394 & 155 & $56-562$ & 227 & 111 \\
\hline \multicolumn{7}{|c|}{ Extractable $\mathrm{P}\left(\mathrm{mg} \mathrm{kg}^{-1}\right)$ by } \\
\hline Olsen/Bray & $11.3-34.3$ & 21.0 & 7.14 & $1.5-18.2$ & 6.8 & 4.9 \\
\hline Mehlich 3 & $3.22-32.5$ & 13.9 & 8.37 & $4.3-25.4$ & 10.0 & 6.0 \\
\hline \multicolumn{7}{|c|}{ Extractable $\mathrm{K}\left(\mathrm{mg} \mathrm{kg}^{-1}\right)$ by } \\
\hline $\mathrm{NH}_{4} \mathrm{OAc}$ & $40.3-231$ & 86.7 & 47.4 & $15.9-189$ & 74.1 & 46.5 \\
\hline Mehlich 3 & $38.9-327$ & 129 & 65.0 & $52.3-260$ & 122 & 57.9 \\
\hline \multicolumn{7}{|c|}{ Extractable $\mathrm{S}\left(\mathrm{mg} \mathrm{kg}^{-1}\right)$ by } \\
\hline $\mathrm{CaCl}_{2}$ & $5.6-17.9$ & 9.9 & 3.7 & $2.2-11.7$ & 6.4 & 2.5 \\
\hline Mehlich 3 & $28.3-82.8$ & 48.7 & 1.0 & $9.0-34.0$ & 22.2 & 6.0 \\
\hline \multicolumn{7}{|c|}{ Extractable $\mathrm{B}\left(\mathrm{mg} \mathrm{kg}^{-1}\right)$ by } \\
\hline Hot-CaCl${ }_{2}$ & $0.34-0.96$ & 0.54 & 0.08 & $0.05-0.43$ & 0.22 & 0.18 \\
\hline Mehlich 3 & $0.33-0.99$ & 0.65 & 0.19 & $0.16-0.67$ & 0.38 & 0.16 \\
\hline \multicolumn{7}{|c|}{ Extractable $\mathrm{Zn}\left(\mathrm{mg} \mathrm{kg}^{-1}\right)$ by } \\
\hline DTPA & $0.52-1.70$ & 0.82 & 0.27 & $0.81-2.30$ & 1.34 & 0.35 \\
\hline Mehlich 3 & $0.50-1.87$ & 0.93 & 0.35 & $1.11-3.65$ & 2.15 & 0.73 \\
\hline
\end{tabular}

The amounts of extractable P, K, S, B and Zn content of the soils by Mehlich 3 and respective conventional methods showed significant positive correlations with organic $\mathrm{C}$ and clay content and CEC (Table 2), but Mehlich 3 extractable $\mathrm{P}$ of both in Alfisols and
Inceptisols showed significant negative correlation with soil $\mathrm{pH}$. The amount of nutrients extracted by Mehlich 3 and conventional methods were significantly and positively correlated with each other (Table 3).

Table 2. Correlations between extractable soil nutrients and soil properties.

\begin{tabular}{|c|c|c|c|c|c|c|c|c|c|}
\hline \multirow[t]{2}{*}{ Nutrients } & \multirow[t]{2}{*}{ Extractant } & \multicolumn{2}{|l|}{$\mathrm{pH}$} & \multicolumn{2}{|l|}{ Organic C } & \multicolumn{2}{|l|}{ Clay } & \multicolumn{2}{|l|}{ CEC } \\
\hline & & Inceptisol & Alfisol & Inceptisol & Alfisol & Inceptisol & Alfisol & Inceptisol & Alfisol \\
\hline \multirow[t]{2}{*}{$\mathrm{P}$} & Olsen/Bray & $0.308^{*}$ & $0.314^{*}$ & $0.844 * *$ & $0.916 * *$ & 0.414 & 0.148 & $0.728 * *$ & $0.845 * *$ \\
\hline & Mehlich 3 & $-0.304^{*}$ & $-0.374 *$ & $0.737 * *$ & $0.891 * *$ & $0.576^{* *}$ & 0.193 & $0.644 * *$ & $0.783 * *$ \\
\hline \multirow[t]{2}{*}{$\mathrm{K}$} & $\mathrm{NH}_{4} \mathrm{OAc}$ & 0.324 & 0.328 & $0.876^{* *}$ & $0.989 * *$ & $0.518^{*}$ & 0.198 & $0.748 * *$ & $0.916^{* * *}$ \\
\hline & Mehlich 3 & 0.257 & 0.279 & $0.884 * *$ & $0.950 * *$ & $0.521 *$ & 0.224 & $0.701 * *$ & $0.900 * *$ \\
\hline \multirow[t]{2}{*}{$\mathrm{S}$} & $\mathrm{CaCl}_{2}$ & 0.160 & $0.468 *$ & $0.854 * *$ & $0.843 * *$ & $0.520 *$ & 0.118 & $0.727 * *$ & $0.746 * *$ \\
\hline & Mehlich 3 & 0.319 & 0.406 & $0.743 * *$ & $0.642 * *$ & $0.562 * *$ & 0.091 & $0.864 * *$ & $0.545^{*}$ \\
\hline \multirow[t]{2}{*}{ B } & Hot-CaCl 2 & 0.432 & $0.458^{*}$ & $0.853 * *$ & $0.821 * *$ & $0.500 *$ & 0.398 & $0.885 * *$ & $0.796 * *$ \\
\hline & Mehlich 3 & 0.419 & 0.465 & $0.723 * *$ & $0.758 * *$ & $0.449 *$ & 0.336 & $0.688 * *$ & $0.706^{* *}$ \\
\hline \multirow[t]{2}{*}{$\mathrm{Zn}$} & M DTPA & -0.193 & -0.240 & $0.891 * *$ & $0.730 * *$ & $0.510 * *$ & 0.206 & $0.766 * *$ & $0.621 * *$ \\
\hline & Mehlich 3 & 0.038 & 0.136 & $0.725 * *$ & $0.839 * *$ & $0.511 *$ & 0.123 & $0.654 * *$ & $0.743 * *$ \\
\hline
\end{tabular}

*and $* *$ indicate significant at $\mathrm{p} \leq 0.05$ and $\mathrm{p} \leq 0.01$ levels, respectively. 
Table 3. Relationships between the amounts of $\mathrm{P}, \mathrm{K}, \mathrm{S}, \mathrm{B}$ and $\mathrm{Zn}$ in soils as extracted by conventional extractants and Mehlich 3.

\begin{tabular}{|c|c|c|c|c|c|c|}
\hline \multirow{2}{*}{$\begin{array}{l}\text { Mehlich 3 } \\
\text { extractable } \\
\text { nutrient }\end{array}$} & \multirow[t]{2}{*}{ Soil } & \multicolumn{5}{|c|}{ Conventional extractant } \\
\hline & & Olsen/Bray & $\mathrm{NH}_{4}-\mathrm{OAc}$ & $\mathrm{CaCl}_{2}$ & Hot- $\mathrm{CaCl}_{2}$ & DTPA \\
\hline \multirow[t]{2}{*}{$\mathrm{P}$} & Inceptisols & $0.853^{* *}$ & & & & \\
\hline & Alfisols & $0.953 * *$ & & & & \\
\hline \multirow[t]{2}{*}{ K } & Inceptisols & & $0.958 * *$ & & & \\
\hline & Alfisols & & $0.961 * *$ & & & \\
\hline \multirow[t]{2}{*}{$\mathrm{S}$} & Inceptisols & & & $0.882 * *$ & & \\
\hline & Alfisols & & & $0.899 * *$ & & \\
\hline \multirow[t]{2}{*}{ B } & Inceptisols & & & & $0.817 * *$ & \\
\hline & Alfisols & & & & $0.938 * *$ & \\
\hline \multirow[t]{2}{*}{$\mathrm{Zn}$} & Inceptisols & & & & & $0.919 * *$ \\
\hline & Alfisols & & & & & $0.919 * *$ \\
\hline
\end{tabular}

\subsection{Biomass yield, concentration and uptake of nu-} trients by rice

Effects of soil and nutrient $(\mathrm{P} / \mathrm{K} / \mathrm{S} / \mathrm{B} / \mathrm{Zn})$ rate were significant for biomass yield of rice, but soil $\times$ nutrient rate interactions were always insignificant (Table 4). This indicated that the effects of nutrient application rate were consistent across the soils. On an average, the increase in biomass yield was 20.8 and $31.2 \%$ in Inceptisols and 20.8 and $37.6 \%$ in Alfisols with 14 and $23 \mathrm{mg} \mathrm{P} \mathrm{kg}^{-1}$ of soil over the control (without $\mathrm{P}$ ). Addition of 23 and $36 \mathrm{mg} \mathrm{K} \mathrm{kg}^{-1}$ of soil, resulted in 12.0 and $28.5 \%$ increase in biomass yield in Inceptisols and 13.6 and $33.1 \%$ in Alfisols, respectively over the $\mathrm{K}_{0}$ treatment; Sulphur application at the rate of 4.5 and $9.0 \mathrm{mg} \mathrm{kg}^{-1}$ soil caused 16.4 and $38.2 \%$ increase in Inceptisols and 26.0 and 46.6\% in Alfisols, respectively over the $\mathrm{S}_{0}$ control. Boron application at the rate of 0.5 and $1.0 \mathrm{mg} \mathrm{kg}^{-1}$ soil in Inceptisols and Alfisols enhanced the biomass yield by 14.6 and $30.7 \%$ and 22.5 and $40.8 \%$, respectively over the $\mathrm{B}_{0}$ control. Biomass yield of rice was also increased by 14.0 and $29.0 \%$ in Inceptisols and 21.3 and $36.7 \%$ in Alfisols with 2.3 and $4.5 \mathrm{mg} \mathrm{Zn} \mathrm{kg}^{-1}$ of soil, respectively over the control. Bray's percent yield varied from 61.1 to $85.0 \%, 65.4$ to $81.6 \%, 56.3$ to $82.9 \%, 59.8$ to $86.4 \%$ and 62.1 to $85.6 \%$ with mean the values of $75.2,76.8$, $70.9,75.9$ and $74.4 \%$ due to the application of P, K, S, $\mathrm{B}$ and $\mathrm{Zn}$, respectively (Figure 1). On an average, the magnitude of increase in biomass yield with $\mathrm{P}, \mathrm{K}, \mathrm{S}, \mathrm{B}$ and $\mathrm{Zn}$ was higher in Alfisols than that in Inceptisols. Concentration and uptake of P, K, S, B and Zn by plants were significantly influenced $(\mathrm{P} \leq 0.01)$ by the nature of soils and rates of nutrients tested, but not by their interactions both in Inceptisols and Alfisols (Table 4). The highest values of nutrient concentration and uptake were always associated with the highest levels of all the nutrients under consideration. 
Table 4. Dry matter yield, nutrient concentration and their uptake by rice plant at 50 days after transplanting

\begin{tabular}{|c|c|c|c|c|c|c|}
\hline \multirow[t]{2}{*}{ Nutrient rate } & \multicolumn{2}{|c|}{$\begin{array}{l}\text { Dry matter yield } \\
\left(\mathrm{g} p o t^{-1}\right)\end{array}$} & \multicolumn{2}{|c|}{$\begin{array}{l}\text { Nutrient concentration } \\
\left(\mathrm{g} \mathrm{kg}^{-1} \text { for } \mathrm{P}, \mathrm{K} \text { and } \mathrm{S} \text {; }\right. \\
\left.\mathrm{mg} \mathrm{kg}^{-1} \text { for } \mathrm{B} \text { and } \mathrm{Zn}\right)\end{array}$} & \multicolumn{2}{|c|}{$\begin{array}{l}\text { Nutrient uptake } \\
\left(\mathrm{mg} \mathrm{pot}^{-1} \text { for } \mathrm{P}, \mathrm{K} \text { and } \mathrm{S} \text {; }\right. \\
\left.\mu \mathrm{g} \text { pot }^{-1} \text { for } \mathrm{B} \text { and } \mathrm{Zn}\right)\end{array}$} \\
\hline & Inceptisols & Alfisols & Inceptisols & Alfisols & Inceptisols & Alfisols \\
\hline $\mathrm{P}_{0}$ & $9.1 \mathrm{a}$ & $6.7 \mathrm{a}$ & $0.150 \mathrm{a}$ & $0.138 \mathrm{a}$ & $16.5 \mathrm{a}$ & $10.8 \mathrm{a}$ \\
\hline $\mathrm{P}_{1}$ & $10.9 b$ & $8.0 \mathrm{~b}$ & $0.188 \mathrm{~b}$ & $0.208 \mathrm{~b}$ & $22.9 b$ & $18.5 b$ \\
\hline $\mathrm{P}_{2}$ & $11.7 \mathrm{c}$ & $8.9 \mathrm{c}$ & $0.257 \mathrm{c}$ & $0.286 \mathrm{c}$ & $33.7 \mathrm{c}$ & $27.1 \mathrm{c}$ \\
\hline $\mathrm{K}_{0}$ & $9.7 \mathrm{a}$ & $7.1 \mathrm{a}$ & $1.64 \mathrm{a}$ & $1.68 \mathrm{a}$ & $171 \mathrm{a}$ & $121 \mathrm{a}$ \\
\hline $\mathrm{K}_{1}$ & $10.9 \mathrm{~b}$ & $8.0 \mathrm{~b}$ & $2.01 \mathrm{~b}$ & $2.22 \mathrm{~b}$ & $232 b$ & $187 b$ \\
\hline $\mathrm{K}_{2}$ & $12.4 \mathrm{c}$ & $9.2 \mathrm{c}$ & $2.52 \mathrm{c}$ & $2.57 \mathrm{c}$ & $325 \mathrm{c}$ & $240 \mathrm{c}$ \\
\hline $\mathrm{S}_{0}$ & $9.5 \mathrm{a}$ & $6.4 \mathrm{a}$ & $0.099 \mathrm{a}$ & $0.090 \mathrm{a}$ & $10.1 \mathrm{a}$ & $6.7 \mathrm{a}$ \\
\hline $\mathrm{S}_{1}$ & $10.9 \mathrm{~b}$ & $8.0 \mathrm{~b}$ & $0.119 b$ & $0.124 b$ & $13.6 \mathrm{~b}$ & $10.6 \mathrm{~b}$ \\
\hline $\mathrm{S}_{2}$ & $12.4 \mathrm{c}$ & $9.1 \mathrm{c}$ & $0.147 \mathrm{c}$ & $0.179 \mathrm{c}$ & $18.6 \mathrm{c}$ & $16.8 \mathrm{c}$ \\
\hline $\mathrm{B}_{0}$ & $9.6 a$ & $6.6 \mathrm{a}$ & $7.24 \mathrm{a}$ & $6.90 \mathrm{a}$ & $56.1 \mathrm{a}$ & $0.326 \mathrm{a}$ \\
\hline $\mathrm{B}_{1}$ & $10.9 \mathrm{~b}$ & $8.0 \mathrm{~b}$ & $9.20 \mathrm{~b}$ & $8.51 \mathrm{~b}$ & $81.7 \mathrm{~b}$ & $0.516 \mathrm{~b}$ \\
\hline $\mathrm{B}_{2}$ & $12.2 \mathrm{c}$ & $9.0 \mathrm{c}$ & $11.9 \mathrm{c}$ & $10.3 \mathrm{c}$ & $125 \mathrm{c}$ & $0.657 \mathrm{c}$ \\
\hline $\mathrm{Zn}_{0}$ & $9.5 \mathrm{a}$ & $6.5 \mathrm{a}$ & $40.0 \mathrm{a}$ & $46.7 \mathrm{a}$ & $0.408 \mathrm{a}$ & $36.1 \mathrm{a}$ \\
\hline $\mathrm{Zn}_{1}$ & $10.9 \mathrm{~b}$ & $8.0 \mathrm{~b}$ & $55.4 \mathrm{~b}$ & $61.7 b$ & $0.641 b$ & $54.8 \mathrm{~b}$ \\
\hline $\mathrm{Zn}_{2}$ & $12.1 \mathrm{c}$ & $8.8 \mathrm{c}$ & $70.2 \mathrm{c}$ & $70.8 \mathrm{c}$ & $0.886 \mathrm{c}$ & $77.8 \mathrm{c}$ \\
\hline \multicolumn{7}{|c|}{ Analysis of variance } \\
\hline Soil & $* *$ & $* *$ & $* *$ & $* *$ & $* *$ & $* *$ \\
\hline $\begin{array}{l}\text { Nutrient } \\
(\mathrm{P} / \mathrm{K} / \mathrm{S} / \mathrm{B} / \mathrm{Zn})\end{array}$ & $* *$ & $* *$ & $* *$ & $* *$ & $* *$ & $* *$ \\
\hline $\begin{array}{l}\text { Soil } \times \text { nutrient } \\
(\mathrm{P} / \mathrm{K} / \mathrm{S} / \mathrm{B} / \mathrm{Zn})\end{array}$ & NS & NS & NS & NS & NS & NS \\
\hline
\end{tabular}

$\mathrm{P}_{0}, \mathrm{~K}_{0}, \mathrm{~S}_{0}, \mathrm{Zn}_{0}$ and $\mathrm{B}_{0}$ is control for respective nutrient; $\mathrm{P}_{1}, \mathrm{~K}_{1}, \mathrm{~S}_{1}, \mathrm{Zn}_{1}$ and $\mathrm{B}_{1}$ is $14 \mathrm{mg} \mathrm{P}, 23 \mathrm{mg} \mathrm{K}, 4.5 \mathrm{mg} \mathrm{S}, 0.5 \mathrm{mg} \mathrm{B}$ and 2.3 $\mathrm{mg} \mathrm{Zn}$ per $\mathrm{kg}$ of soil; $\mathrm{P}_{2}, \mathrm{~K}_{2}, \mathrm{~S}_{2}, \mathrm{Zn}_{2}$ and $\mathrm{B}_{2}$ is $23 \mathrm{mg} \mathrm{P}, 36 \mathrm{mg} \mathrm{K}, 9.0 \mathrm{mg} \mathrm{S}, 1.0 \mathrm{mg} \mathrm{B}$ and $4.5 \mathrm{mg} \mathrm{Zn}$ per kg of soil. Values are means of 20 soils for each of the soil orders Inceptisol and Alfisol. Means followed by a different letter are significantly different at $\mathrm{P} \leq 0.05$ by Duncan multiple-range test. ** indicate significant at $\mathrm{P} \leq 0.01$; NS, not significant at $\mathrm{P} \leq 0.05$.

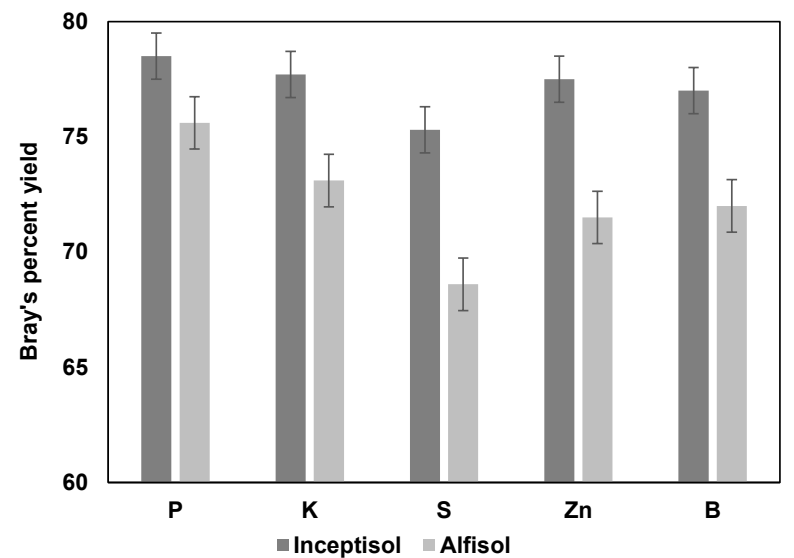

Figure 1. Average Bray's percent yield of rice at 50 days after transplanting in response to application of $\mathrm{P}$, K, $\mathrm{S}$, $\mathrm{B}$ and $\mathrm{Zn}$ in soils (error bars represent the standard error of mean). 


\subsection{Relationships of Mehlich 3 extractable soil nutri- ents with plant parameters}

The amounts of $\mathrm{P}, \mathrm{K}, \mathrm{S}, \mathrm{B}$ and $\mathrm{Zn}$ as extracted by Mehlich 3 and conventional extractants showed significant positive correlations $(\mathrm{P} \leq 0.01)$ with biomass yield, nutrients concentration and their uptake by rice (Table 5). The strength of relationships (r) for Mehlich
3 extractable $\mathrm{P}$ with the above parameters was stronger in Alfisols compared to Inceptisols; but it was weaker in Alfisols than in Inceptisols for K, S, B and $\mathrm{Zn}$. Such relationships of the amount of $\mathrm{P}, \mathrm{K}, \mathrm{S}, \mathrm{Zn}$ and $\mathrm{B}$ in soils with biomass yield, concentration of those nutrients and their uptake by rice were stronger when the nutrients were extracted by the conventional methods compared to the Mehlich 3 one for both Alfisols and Inceptisols.

Table 5. Correlation coefficient between extractable nutrients and dry-matter yield, concentration, uptake of nutrients and Bray's percent yield (BPY) of rice.

\begin{tabular}{|c|c|c|c|c|c|c|c|c|c|c|c|}
\hline Nutrient & Extractant & $\mathrm{Y}_{0}$ & $\mathrm{Y}_{1}$ & $\mathrm{Y}_{2}$ & $\mathrm{C}_{0}$ & $\mathrm{C}_{1}$ & $\mathrm{C}_{2}$ & $\mathrm{U}_{0}$ & $\mathrm{U}_{1}$ & $\mathrm{U}_{2}$ & BPY \\
\hline \multicolumn{12}{|c|}{ Inceptisols } \\
\hline \multirow{2}{*}{$\mathrm{P}$} & Olsen/Bray & $0.947 * *$ & $0.924 * *$ & $0.956^{* *}$ & $0.921 * *$ & $0.919 * *$ & $0.865 * *$ & $0.954 * *$ & $0.937 * *$ & $0.899 * *$ & $0.829 * *$ \\
\hline & Mehlich 3 & $0.899 * *$ & $0.877 * *$ & $0.878 * *$ & $0.812^{* *}$ & $0.765 * *$ & $0.782 * *$ & $0.902 * *$ & $0.883 * *$ & $0.834 * *$ & 0.771 ** \\
\hline \multirow{2}{*}{$\mathrm{K}$} & $\mathrm{NH}_{4} \mathrm{OAc}$ & $0.957 * *$ & $0.957 * *$ & $0.948 * *$ & $0.889 * *$ & $0.908 * *$ & $0.895^{* *}$ & $0.977 * *$ & $0.982 * *$ & $0.968 * *$ & $0.821 * *$ \\
\hline & Mehlich 3 & $0.929 * *$ & $0.922 * *$ & $0.903 * *$ & $0.871 * *$ & $0.879 * *$ & $0.868 * *$ & $0.935 * *$ & $0.951 * *$ & $0.941 * *$ & $0.782^{* *}$ \\
\hline \multirow{2}{*}{$\mathrm{S}$} & $\mathrm{CaCl}_{2}$ & $0.893 * *$ & $0.908 * *$ & $0.891 * *$ & $0.783 * *$ & $0.799 * *$ & $0.781 * *$ & $0.903 * *$ & $0.901 * *$ & $0.892 * *$ & $0.821^{* *}$ \\
\hline & Mehlich 3 & $0.782 * *$ & $0.808 * *$ & $0.774 * *$ & $0.665^{* *}$ & $0.678^{* *}$ & $0.777^{* *}$ & $0.798 * *$ & $0.798 * *$ & $0.809 * *$ & $0.755^{* *}$ \\
\hline \multirow{2}{*}{ B } & Hot- $\mathrm{CaCl}_{2}$ & $0.920 * *$ & $0.932 * *$ & $0.915^{* *}$ & $0.722 * *$ & $0.851^{* *}$ & $0.812 * *$ & $0.891 * *$ & $0.938 * *$ & $0.917 * *$ & $0.825^{* *}$ \\
\hline & Mehlich 3 & $0.796^{* *}$ & $0.745^{* * *}$ & $0.766^{* *}$ & $0.548^{*}$ & $0.774 * *$ & $0.729 * *$ & $0.779 * *$ & $0.763 * *$ & $0.700 * *$ & $0.786^{* *}$ \\
\hline \multirow{2}{*}{$\mathrm{Zn}$} & DTPA & $0.877 * *$ & $0.884 * *$ & $0.849 * *$ & $0.900 * *$ & $0.908 * *$ & $0.895 * *$ & $0.821 * *$ & $0.877 * *$ & $0.884 * *$ & $0.849 * *$ \\
\hline & Mehlich 3 & $0.716^{* *}$ & $0.731 * *$ & $0.728 * *$ & $0.886^{* *}$ & $0.883 * *$ & $0.863 * *$ & $0.731 * *$ & $0.716^{* *}$ & $0.731 * *$ & $0.728 * *$ \\
\hline \multicolumn{12}{|c|}{ Alfisols } \\
\hline \multirow{2}{*}{$\mathrm{P}$} & Olsen/Bray & $0.882 * *$ & $0.921 * *$ & $0.820 * *$ & $0.838 * *$ & $0.804 * *$ & $0.907 * *$ & $0.918 * *$ & $0.924 * *$ & $0.643 * *$ & $0.882^{* *}$ \\
\hline & Mehlich 3 & 0.880 ** & $0.907 * *$ & $0.799 * *$ & $0.798 * *$ & $0.801 * *$ & $0.890 * *$ & $0.903 * *$ & $0.920 * *$ & $0.620 * *$ & $0.880 * *$ \\
\hline \multirow{2}{*}{$\mathrm{K}$} & $\mathrm{NH}_{4} \mathrm{OAc}$ & $0.953 * *$ & $0.960 * *$ & $0.961 * *$ & $0.955^{* *}$ & $0.937 * *$ & $0.931 * *$ & $0.981 * *$ & $0.972 * *$ & $0.978 * *$ & $0.730^{* *}$ \\
\hline & Mehlich 3 & $0.883 * *$ & $0.919 * *$ & $0.898 * *$ & $0.940 * *$ & $0.911 * *$ & $0.927 * *$ & $0.945 * *$ & $0.955^{* *}$ & $0.944 * *$ & $0.696^{* *}$ \\
\hline \multirow{2}{*}{$\mathrm{S}$} & $\mathrm{CaCl}_{2}$ & $0.734 * *$ & $0.768 * *$ & $0.732 * *$ & $0.724 * *$ & $0.644 * *$ & $0.680^{* *}$ & $0.803 * *$ & $0.801 * *$ & $0.770 * *$ & $0.540^{*}$ \\
\hline & Mehlich 3 & $0.630 *$ & $0.668 * *$ & $0.543^{*}$ & $0.687 * *$ & $0.585^{*}$ & $0.497 *$ & $0.698 * *$ & $0.582 * *$ & $0.592 * *$ & $0.485^{*}$ \\
\hline \multirow{2}{*}{ B } & Hot- $\mathrm{CaCl}_{2}$ & $0.806^{* *}$ & $0.851 * *$ & $0.780^{* *}$ & $0.575^{* *}$ & $0.763^{* *}$ & $0.579 * *$ & $0.786^{* *}$ & $0.858 * *$ & $0.759^{* *}$ & $0.739^{* *}$ \\
\hline & Mehlich 3 & $0.738 * *$ & $0.769 * *$ & $0.776^{* *}$ & $0.541^{*}$ & $0.757 * *$ & $0.532 *$ & $0.697 * *$ & $0.783 * *$ & $0.697 * *$ & $0.691 * *$ \\
\hline \multirow{2}{*}{$\mathrm{Zn}$} & DTPA & $0.691 * *$ & $0.722 * *$ & $0.772 * *$ & $0.849 * *$ & $0.802 * *$ & $0.814^{* *}$ & $0.656^{* *}$ & $0.691 * *$ & $0.722 * *$ & $0.772 * *$ \\
\hline & Mehlich 3 & $0.804 * *$ & $0.834 * *$ & $0.807^{* *}$ & $0.852 * *$ & $0.862 * *$ & $0.860 * *$ & $0.807 * *$ & $0.804 * *$ & $0.834 * *$ & $0.807^{* *}$ \\
\hline
\end{tabular}

$\mathrm{Y}_{0}, \mathrm{C}_{0}$ and $\mathrm{U}_{0}$ are dry-matter yield, concentration and uptake of nutrients in response to $\mathrm{P}_{0} / \mathrm{K}_{0} / \mathrm{S}_{0} / \mathrm{B}_{0} / \mathrm{Zn}_{0}$ treatment, respectively; $\mathrm{Y}_{1}, \mathrm{C}_{1}$ and $\mathrm{U}_{1}$ are dry-matter yield, concentration and uptake of nutrients in response to $\mathrm{P}_{1} / \mathrm{K}_{1} / \mathrm{S}_{1} / \mathrm{B}_{1} / \mathrm{Zn}_{1}$ treatment, respectively; $\mathrm{Y}_{2}, \mathrm{C}_{2}$ and $\mathrm{U}_{2}$ are dry-matter yield, concentration and uptake of nutrients in response to $\mathrm{P}_{2} / \mathrm{K}_{2} / \mathrm{S}_{2} / \mathrm{B}_{2} / \mathrm{Zn}_{2}$ treatment, respectively. *and $* *$ indicate significant at $\mathrm{p} \leq 0.05$ and $\mathrm{p} \leq 0.01$ levels, respectively. 


\subsection{Critical limits of soil $P, K, S, B$ and Zn by Mehlich} 3 for rice

The critical limits of Mehlich 3 extractable P, K, S, $\mathrm{B}$ and $\mathrm{Zn}$ for nutrition of rice as determined by the statistical methods of Cate and Nelson (1971) varied significantly between the two soil orders. Its values for $\mathrm{P}, \mathrm{K}$ and $\mathrm{S}$ were $14.7,51.2$ and $22.9 \mathrm{mg} \mathrm{kg}^{-1}$ in Inceptisols; whereas, 8.2, 117.3 and $21.9 \mathrm{mg} \mathrm{kg}^{-1}$ in Alfisols, respectively. The critical limits computed for $\mathrm{B}$ and $\mathrm{Zn}$ were 0.65 and $0.40 \mathrm{mg} \mathrm{kg}^{-1}$ and 1.27 and $2.15 \mathrm{mg} \mathrm{kg}^{-1}$ in Inceptisols and Alfisols, respectively.

\section{Discussion}

Extractants used in this study have varied ability to extract varying portions of soil $\mathrm{P}, \mathrm{K}, \mathrm{S}, \mathrm{B}$ and $\mathrm{Zn}$, because they (extractants) target different pools of soil nutrients. The acetic acid in Mehlich 3 aided the extraction of $\mathrm{P}$ from soil by promoting the dissolution of phosphates bound with $\mathrm{Ca}$, whereas, the presence of fluoride facilitated the extraction of phosphates associated with $\mathrm{Fe}$ and $\mathrm{Al}$ (Shahandeh et al., 2017; Wuenscher et al., 2015). Mehlich 3 also extracted higher amounts of $\mathrm{K}$ and $\mathrm{S}$ from soils than those with ammonium acetate (Mehlich, 1984) and $\mathrm{CaCl}_{2}$ (Rao and Sharma, 1997) extractants, respectively. Ammonium nitrate and nitric acid in Mehlich 3 effectively extracted exchangeable $\mathrm{K}$; while its acetate and nitrate anions favored the extraction of $\mathrm{S}$ from soil. Similarly, Zbiral (2016) observed a higher amount of extractable B with Mehlich 3 than that with hotwater since acetate and fluoride anions in Mehlich 3 could effectively displace B from specific sorption sites. The extractability of Mehlich 3 for soil $\mathrm{Zn}$ was also higher than that of the conventional DTPA extractant because $\mathrm{Zn}$ in soils could be dissolved and complexed by ammonium nitrate and EDTA, respectively (Seth et al., 2017). Soil properties are known to influence extraction of essential plant nutrients from soil by the chemical extractants. Such properties include clay, organic $\mathrm{C}, \mathrm{Fe}, \mathrm{Al}$ and $\mathrm{Mn}$ oxides content and $\mathrm{pH}$ and CEC of soils (Seth et al., 2017; Sarkar et al., 2008). The relationships of extractable P, K, S, B and $\mathrm{Zn}$ content with organic $\mathrm{C}$ and clay content and CEC (Table 2) were comparable to those reported by other researchers (Seth et. al., 2017; Zbiral, 2016; Rengel, 2015; Wuenscher et al., 2015). Existence of significant positive correlations (Table 3 ) between the amounts of nutrients extracted by Mehlich 3 and conventional extractants indicated that they extracted the nutrients from almost similar pools in soil.

Supply of individual nutrient $(\mathrm{P} / \mathrm{K} / \mathrm{S} / \mathrm{B} / \mathrm{Zn})$ caused significant increase in dry matter yield of rice in Inceptisols and Alfisols, when all other nutrients were at optimum level. This was due to maintenance of higher availability of the individual nutrient in question, which was indicated by its $(\mathrm{P} / \mathrm{K} / \mathrm{S} / \mathrm{B} / \mathrm{Zn})$ greater uptake (Table 4) when supplied through fertilizers. The higher uptake of nutrients might increase photosynthetic activities of plants, which ultimately helped to realize better crop growth in terms of yield related parameters and thus productivity. Comparable response of crops to $\mathrm{P} / \mathrm{K} / \mathrm{S} / \mathrm{B} / \mathrm{Zn}$ application was reported from tropical and subtropical regions (Seth et al., 2017; Teixeira et al., 2016; Sarkar et al., 2008).

The suitability of different extractants for assessing plant available soil nutrient is a function of the nature of soils and the crop type. For example, the hot- $\mathrm{CaCl}_{2}$ method of Parker and Gardner (1981) was proved to be suitable for assessment of plant available B in acidic soils for nutrition of mustard (Brassica campestris L.) and wheat (Triticum aestivum L.) (Sarkar et al., 2008). The Mehlich 3 extractable P, K, S, B and $\mathrm{Zn}$ showed significant positive correlations $(\mathrm{P} \leq$ 0.01 ) with biomass yield, nutrients concentration and their uptake by rice (Table 5) in Inceptisols and Alfisols. Further, Mehlich 3 could simultaneously extract 
all the five nutrients (P, K, S, Zn and B) from soils compared to only one by their respective conventional method and its use would be time saving and economic. Suitability of Mehlich 3 as a useful extractant was also proved by Mamo et al. (1996) for P, K and S, Rao and Sharma (1997) for Zn and Walworth et al. (1992) for B. All these results lead us to opine that Mehlich 3 may be recommended for routine laboratory analysis for assessment of available P, K, S, B and Zn for nutrition of rice in Inceptisols and Alfisols.

Determination of critical concentrations of plant available nutrients in soil is useful for an early diagnosis of nutrient deficiency to crop in order to take adequate measures before sowing/transplanting of crops. Similar critical limits of Mehlich 3 extractable $\mathrm{P}$ and $\mathrm{K}$ as observed in this experiment were reported for field crops elsewhere (Slaton et al., 2005; Slton et al., 2005; Coax and Barnes, 2002). Zbiral (2016) also reported critical limits of Mehlich 3 extractable B and $\mathrm{Zn}$ of 0.7 and $2.2 \mathrm{mg} \mathrm{kg}^{-1}$ in soils of Czech Republic, respectively. The observed critical limits for $\mathrm{K}$ and $\mathrm{Zn}$ were 2.3 and 1.7 times greater in Alfisols than those in Inceptisols; whereas for P and B such values were 1.8 and 1.6 times greater in Inceptisols than those in Alfisols, respectively. Under submerged conditions in Alfisols, $\mathrm{Zn}$ is scavenged by increased formation of amorphous sesquioxides making it $(\mathrm{Zn})$ unavailable to plants (Mandal et al., 1992). Such transformation of $\mathrm{Zn}$ may be responsible for the observed higher critical limits of $\mathrm{Zn}$ for rice in Alfisols than Inceptisols. High leaching loss and minimum supply of mineral-K in Alfisols (Khurana et al., 2008) are the possible reasons for its (K) higher critical value.

Based on the critical values of Mehlich 3 extractable P, K, S, B and Zn, the experimental soils were grouped into two classes: below and above critical limit for both soil orders. Of 20 soils, 11, 2, 12, 9 and 15 in Inceptisols and 11, 10, 9, 12 and 9 in Alfisols were below critical level of Mehlich 3 extractable P,
$\mathrm{K}, \mathrm{S}, \mathrm{B}$ and $\mathrm{Zn}$, respectively. On an average, increase in biomass yield of rice grown on Inceptisols below and above critical level of P, K, S, B and $\mathrm{Zn}$ were 29.8, 21.2, 31.6, 24.3 and $23 \%$ and 21.4, 11.9, 20.2, 21.3 and $15.6 \%$; whereas, such increase in yield of rice on Alfisols were 36.3, 28.0, 41.3, 36.7 and 33.7\% and $17.7,18.6,33.5,23.6$ and $25.2 \%$, respectively. This indicated that response of rice to application of $\mathrm{P}, \mathrm{K}, \mathrm{S}, \mathrm{B}$ and $\mathrm{Zn}$ was always higher in soils with Mehlich 3 extractable P, K, S, B and Zn content below the critical level than that above the critical level, respectively.

\section{Conclusions}

Like conventional methods, Mehlich 3 was also found to be a good extractant for assessing P, K, S, B and Zn content in both Alfisols and Inceptisols for their nutrition of rice. The critical levels of Mehlich 3 extractable $\mathrm{P}, \mathrm{K}, \mathrm{S}, \mathrm{B}$ and $\mathrm{Zn}$ for rice in Inceptisols were $14.7,51.2,22.9,0.65$ and $1.27 \mathrm{mg} \mathrm{kg}^{-1}$; while in Alfisols those values were 8.2, 117.3, 21.9, 0.40 and 2.15 $\mathrm{mg} \mathrm{kg}{ }^{-1}$, respectively.

\section{Acknowledgement}

The senior author (AS) is thankful to the Department of Agriculture and Farmers' Welfare, Government of India for providing the Senior Research Fellowship to her during the study.

\section{References}

Bado, B.V., De Vries, M.E., Haefele, S.M., Marco, M.C.S., Ndiaye, M.K. 2007. Critical limit of extractable phosphorous in a gleysol for rice production in the Senegal river valley of West Africa. Commun. Soil Sci. Plant Anal. 39, 202-206. 
Bhattacharyya, R., Ghosh, B.N., Mishra, P.K., Mandal, B., Rao, C.S., Sarkar, D., Das, K., Anil, K.S., Lalitha, M., Hati, K.M., Franzluebbers, A.J. 2015. Soil degradation in India: challenges and potential solutions. Sustainability 7, 3528-3570.

Bray, R.H., Kurtz, L.T. 1945. Determination of total, organic and available forms of phosphorus in soil. Soil Sci. 59, 39-45.

Cate, R.B.Jr., Nelson, L.A. 1971. A simple statistical procedure for partitioning soil test data into two classes. Soil Sci. Soc. Am. Proc. 35, 658-660.

Chesnin, L., Yien, C.H. 1950. Turbidimetric determination of available sulphates. Soil Sci. Soc. Am. Proc. 14, 149-151.

Cox, F.R., Barnes, J.S. 2002. Peanut, corn, and cotton critical levels for phosphorus and potassium on goldsboro soil. Commun. Soil Sci. Plant Anal. 33, 1173-1186.

Gaines, T.P., Mitchell, G.A. 1979. Boron determination in plant tissue by the azomethine-H method. Commun. Soil Sci. Plant Anal. 10, 1099-1108.

Gnanamanickam, S.S. 2009. Rice and its importance to human life. Prog. Biol. Con. 8, 1-11.

Green, A.J. 1981. Particle-size analysis. In: Manual on Soil Sampling and Methods of Analysis. Canadian Soc. Soil Sci., Ottawa, Ontario, Canada, pp. 4-29.

Hanway, J.J., Heidel, H. 1952. Soil analysis methods as used in Iowa State College Soil Testing Laboratory. Iowa Agric. 57, 1-31.

Khurana, M.P.S., Sadana, U.S. Singh, B. 2008. Sulfur nutrition of crops in the Indo-Gangetic of South Asia. In: Sulfur, a Missing Link between Soils, Crops, and Nutrition. Agron. Monog. 50. ASA, CSSA, SSSA, Madison, WI, USA, pp. 11-24.

Kumari, K., Prasad, J., Solanki, I.S., Chaudhary, R. 2018. Long-term effect of crop residues incorporation on yield and soil physical properties under rice-wheat cropping system in calcareous soil. J. Soil Sci. Plant Nutr. 18 (1), 27- 40.

Ladha, J.K., Pathak, H., Tirol-Padre, A., Dawe, D. 2003. Productivity trends in intensive rice-wheat cropping systems in Asia. In: Improving the productivity and sustainability of rice-wheat systems, Issues and impacts. ASA Spec. Publ. 65, ASA, CSSA, SSSA, Madison, WI. pp. 45-76.

Lindsay, W.L., Norvell, W.A. 1978. Development of a DTPA soil test for zinc, iron, manganese and copper. Soil Sci. Soc. Am. J. 42, 421-428.

Mamo, T., Richter, C., Heiligtag, B. 1996. Comparison of extractants for the determination of available phosphorus, potassium, calcium, magnesium and sodium in some Ethiopian and German soils. Commun. Soil Sci. Plant Anal. 27, 2197-2212.

Mandal, B., Chatterjee, J., Hazra, G.C., Mandal, L.N. 1992. Effect of preflooding on transformation of applied zinc and its uptake by rice in lateritic soils. Soil Sci. 153, 250-257.

Mandal, L.N., Mandal, B. 1986. Zinc fractions in soils in relation to zinc nutrition of lowland rice. Soil Sci. 142, 141-148.

Mehlich, A. 1984. Mehlich No. 3 soil test extractant, A modification of Mehlich No. 2. Commun. Soil Sci. Plant Anal. 15, 1409-1416.

Olsen, S.R., Cole, C.V., Watanabe, F.S., Dean, L.A. 1954. Estimation of available phosphorus in soils by extraction with sodium bicarbonate. USDA. Circ. 939.

Parker, D.R., Gardner, E.H. 1981. The determination of hot water soluble boron in some acid Oregon soils using a modified azomethine-H procedure. Commun. Soil Sci. Plant Anal. 12, 1311-1322.

Pradhan, A.K., Beura, K.S., Das, R., Padhan, D., Hazra, G.C., Mandal, B., De, N., Mishra, V.N., Polara, K.B., Sharma, S. 2015. Evaluation of extractability of different extractants for zinc and copper in 
soils under long-term fertilization. Plant Soil Environ. 61, 227-233.

Rao, T.N., Sharma, P.K. 1997. Evaluation of Mehlich 3 as an extractant for available soil sulfur. Commun. Soil Sci. Plant Anal. 28, 1033-1046.

Rengel, Z. 2015. Availability of Mn, Zn and Fe in the rhizosphere. J. Soil Sci. Plant Nutr., 15 (2), 397409.

Sarkar, D., Mandal, B., Mazumdar, D. 2008. Plant availability of boron in acid soils as assessed by different extractants. J. Plant Nutr. Soil Sci. 171, 249-25.

Seth, A., Sarkar, D., Datta, A., Mandal, B., Chowdhury, A., Masto, R.E., Chakravarty, A.K., Hazra, G.C., Badole, S., Batyabal, K., Saha, S. 2017. Suitability of complex extractants for assessment of available soil zinc for nutrition of rice (Oryza sativa L.) in subtropical India. Soil Sci. 182, 2835.

Shahandeh, H., Hons, F.M., Provin, T.L., Pitt, J.L., Waskom, J.S. 2017. Factors affecting Mehlich III soil test methodology for extractable P. Commun. Soil Sci. Plant Anal. 48, 423-438.

Slaton, N.A., Brye, K.R., Bacon, R.K., Mozaffari, M. 2005. Correlation and calibration of Mehlich-3 phosphorus recommendations for winter wheat following rice in Arkansas. Commun. Soil Sci. Plant Anal. 36, 993-1004.

Slaton, N.A., Golden, B.R., Norman, R.J., Wilson, C.E., DeLong, R.E. 2009. Correlation and calibration of soil potassium availability with rice yield and nutritional status. Soil Sci. Soc. Am. J. 73, 1192-1201.
Sparks, D.L., Page, A.L., Helmke, P.A., Loeppert, R.H., Soltanpour, P.N., Tabatabai, M.A., Johnston, C.T., Sumner, C.T. 1996. Methods of Soil Analysis, Part 3. SSSA, ASA, Madison, WI, USA.

Tandon, H.L.S. 1995.Methods of analysis of soils, plants, waters and fertilizers. FDCO, New Delhi, India.

Teixeira, R.S., da Silva, I.R., de Sousa, R.N., Mattiello, E.M., Soares, E.M.B. 2016. Organic acid coated-slow-release phosphorus fertilizers improve $\mathrm{P}$ availability and maize growth in a tropical soil. J. Soil Sci. Plant Nutr. 16, 1097-1112.

Walkley, A., Black, I.A. 1934. An examination of the Degtjareff method for determining soil organic matter and a proposed modification of the chromic acid titration method. Soil Sci. 37, 29-38.

Walworth, J.L., Gavlak, R.G., Panciera, M.T. 1992. Mehlich 3 extractant for available B, Cu, Fe, Mn and $\mathrm{Zn}$ in Cryic Alaskan soils. Can. J. Soil Sci. 72, 517-526.

Wendt, J.W. 1995. Evaluation of the Mehlich 3 soil extractant for upland Malawi soils. Commun. Soil Sci. Plant Anal. 26, 687-602.

Wuenscher, R., Unterfrauner, H., Peticzka, R., Zehetner, F. 2015. A comparison of 14 soil phosphorus extraction methods applied to 50 agricultural soils from Central Europe. Plant Soil Environ. 61, 8696.

Zbiral, J. 2016. Determination of plant-available micronutrients by the Mehlich 3 soil extractant - a proposal of critical values. Plant Soil Environ. 62, 527-531. 